\title{
Study on Awareness of Covid-19, Anxiety and Compliance on Social Distancing in Indonesia During Coronavirus Disease 2019 (COVID-19) Pandemic
}

Rully Afrita Harlianty

Aisyah University of Pringsewu

Tria Widyastuti

State University of Yogyakarta https://orcid.org/0000-0003-4367-9239

Hamid Mukhlis ( $\square$ me@hamidmukhlis.id)

Aisyah University of Pringsewu https://orcid.org/0000-0003-1022-1678

Susi Susanti

Hasanuddin University

\section{Research Article}

Keywords: Awareness of COVID-19, Anxiety, Compliance with Social Distancing

Posted Date: July 20th, 2020

DOI: https://doi.org/10.21203/rs.3.rs-44598/v1

License: (c) (i) This work is licensed under a Creative Commons Attribution 4.0 International License. Read Full License

Version of Record: A version of this preprint was published at Journal of Community Psychology on October 29th, 2021. See the published version at https://doi.org/10.1002/jcop.22735. 


\section{Abstract}

The psychological problem that can arise due to uncertain conditions to the spread of COVID-19 is anxiety. One of the essential behaviors that contribute to the prevention of the spread of COVID-19 is awareness related to COVID-19 and the behavior of community adherence to the appeal of Social Distancing. The research objective was to determine whether awareness of COVID-19 is associated with anxiety and community compliance with social distancing rules. Besides, to understand differences in awareness of COVID-19, anxiety, and community compliance with social distancing rules. Based on an online survey through Google Form was conducted on 404 respondents aged 18 to 63 years. Data were collected using three instruments, the COVID-19 awareness scale, the Depression Anxiety Stress Scale (DASS) anxiety subscale, and the compliance scale for social distancing. Data were analyzed using Spearman correlation and Kruskal Wallis, followed by Mann-Whitney U with Bonferroni correction. The main results of the research found that awareness of COVID-19 plays a vital role in realizing community compliance with social distancing rules. The group that needs more attention is related to awareness of lower COVID-19 and more at risk of experiencing anxiety, namely the younger age group, less educated, and not working. The government need to pay more attention to at-risk groups and provide an official information channel for raising awareness of COVID-19, clear prevention policies, and health protocols to prevent the spread of COVID-19 especially with the discourse for new normal people are asked to move back in the middle of the COVID-19 pandemic.

\section{Introduction}

Coronavirus Disease 2019 (COVID-19) is a group of pneumonia virus cases that began in Wuhan, Hubei Province since December 2019. Since the outbreak of the coronavirus, the spread of coronavirus has occurred around the world so that on March 11 ${ }^{\text {st }}, 2020$ WHO (World Health Organization) state that COVID19 as a pandemic with a total 114 countries exposed to COVID-19 (WHO, 2020a). Reporting from the WHO website (World Health Organization), on June $26^{\text {th }}, 2020$ there were 9.472 .473 reported cases of positive COVID-19 confirmed on a global scale with 484.236 reported death cases. In Indonesia, it have been reported 51.427 got positive COVID-19 cases with 2.683 death cases (WHO, 2020b).

Various countries have implemented lock-down and social distancing policies to minimize the spread of Covid-19 virus infections between humans. The Government of Indonesia applies Stay at Home or Social Distancing policies, as well as Large Scale Social Restrictions (LSSR) in 2 provinces and 22 regencies or cities in Indonesia (Kunjana, 2020). In order for the implementation of the social distancing policy to proceed, community awareness is needed to comply with the regulation. Based on the reports from the Government of Garut Regency, West Java, there are still many members of the community who lack awareness in facing the COVID-19 pandemic that occurred in Garut Regency (Yusuf, 2020). Lack of community awareness causes low compliance to conduct social / physical distancing. Government of South Tangerang City also reported that community compliance with the LSSR rules was still low at around $60 \%$, and would be considered successful if it achieved $80-90 \%$ compliance with the rules (Kurniawan, 2020). 
Compliance with social distancing is needed in order to reduce the spread of viruses that are transmitted from person to person. According to (Ahmed et al., 2018), compliance with social distancing interventions, especially in the workplace, will reduce virus transmission. (Milne \& Xie, 2020) also reported the highest reduction in the attack rate of COVID-19 infection achieved with rapid activation of all available social distancing interventions, and with a high level of compliance. Other research results also report that social distancing behavior is influenced by awareness during the COVID-19 pandemic (Qazi et al., 2020). Social distancing behavior can be enhanced by increasing awareness of COVID-19 through reliable sources of information. Through reliable sources of information about COVID-19 and its prevention make individuals more aware so as to increase social distancing.

Psychological problems such as anxiety are also experienced by individuals during the COVID-19 pandemic (Ifdil et al., 2020; Roy et al., 2020; Wang et al., 2020). Such anxiety results in individuals experiencing paranoids being infected with corona, worrying about themselves and those closest to them during a pandemic, and having trouble sleeping due to worry (Cao et al., 2019; Roy et al., 2020). Anxiety during corona can also lead to depression (Ho et al., 2020; Wang et al., 2020). That is because during the corona emergency, people who have anxiety tend to be depressed and people who are depressed tend to be anxious. The research conducted by (Mishra et al., 2016) state that individuals who have better health awareness, positive attitudes about their epidemic / pandemic often experience low levels of anxiety. Anxiety and depression are influenced by awareness of natural and social disasters. Having an understanding of information related to disasters leads to lower anxiety symptoms (E. Lee \& Lee, 2019).

Based on background of the study, the researchers will analyze the correlation between awareness of COVID-19 with anxiety and compliance on social distancing. In addition, to understand the differences in awareness of COVID-19, anxiety, and community compliance on social distancing rules. Previous studies have examined more descriptively, not many studies have examined the correlation between awareness of COVID-19 with anxiety and compliance on social distancing, especially in Indonesia.

\section{Methods}

The online survey was carried out using Google Form which was shared through various social media platforms such as Instagram, WhatsApp, Email, Facebook and Twitter. The researchers provide a credit reward of Rp. 25.000 for 12 lucky respondents. Based on data collected on $19^{\text {th }}-26^{\text {th }}$ May 2020 there were 408 incoming responses. From the 408 responses that were received, 4 responses were aborted due to duplication of filling so that only 404 data were analyzed further.

Data collection uses a Likert scale consisting of the awareness scale of COVID-19, Depression Anxiety Stress Scale (DASS) anxiety subscale, and compliance scale on social distancing. The COVID-19 awareness scale consists of 15 items with 5 response choices from 1 (highly inappropriate) to 5 (very appropriate). The anxiety subscale DASS consists of 14 items which are part of 42 DASS items developed 
by (Lovibond \& Lovibond, 1995; Page et al., 2007) and adapted into Indonesian (Damanik, 2006, 2011). The response choice of the DASS anxiety subscale consists of 4 choices from 0 (never), 1 (sometimes), 2 (quite often), and 3 (very often). The compliance on social distancing scale consists of 14 items with 4 response choices from 1 (highly inappropriate) to 4 (very appropriate).

Table 1. Information of Reliability Instrument

\begin{tabular}{lccc}
\hline \multicolumn{1}{c}{ Scale } & Total Items & Item Discrimination & Reliability \\
\hline Awareness of Covid-19 & 15 & $.339-.578$ & .831 \\
DASS anxiety subscale & 14 & $.349-.647$ & .842 \\
\hline Compliance on Social Distancing & 15 & $.309-.545$ & .778 \\
\hline
\end{tabular}

Descriptive statistics calculated to summarize respondent data based on demographic data. Data were further analyzed using the Spearman Correlation to test the correlations between variables, Kruskal Wallis and Mann-Whitney $\mathrm{U}$ to compare between demographic groups including gender, employment status, age, education level, and income level. In the Kruskal Wallis test with significant results, the researchers conducted a follow-up analysis with Mann-Whitney accompanied by Bonferonni's correction to conduct the Post hoc test as suggested by (Field, 2009) to avoid Type Eror I.

\section{Results And Discussion}

\section{Subject Characteristics}

Subjects consisted of 404 respondents ( $23.5 \%$ male and $76.5 \%$ female) aged 18 to 63 years (Mean $=27.17$, $\mathrm{SD}=8.468)$. The subject of Education level varies from high school /equivalent graduates $(35.1 \%)$, Associate's degree / Undergraduate (32.4\%), and postgraduate (32.4\%). For the subjects of income level have varying income levels, that is < Rp. 1.000 .000 as much as $41.6 \%$, Rp. $1.000 .000-$ Rp. 3.000 .000 a number of $22.5 \%$, Rp. 3.000 .000 - Rp. 5.000 .000 amount to $22.3 \%$ and> Rp. 5,000,000 13.6\%. Most subjects worked ( $57.7 \%$ vs $42.3 \%$ did not work).

Table 2. The Characteristics of Demographic Subject ( $N=404)$

\begin{tabular}{llcc}
\hline \multicolumn{1}{c}{ Variable } & \multicolumn{1}{c}{ Distribution } & Frequency & $\%$ \\
\hline Age & $18-30$ & 300 & 74.3 \\
& $31-45$ & 84 & 20.8 \\
\hline \multirow{2}{*}{ Gender } & $>46$ & 20 & 5.0 \\
\hline \multirow{2}{*}{ Education } & Male & 95 & 23.5 \\
\hline \multirow{5}{*}{ Income } & Female & 309 & 76.5 \\
\hline & Ungh School & 142 & 35.1 \\
\hline & Postgraduate & 131 & 32.4 \\
\hline & $<1.000 .000$ IDR & 131 & 32.4 \\
\hline \multirow{2}{*}{ Work Status } & Unemployed & 168 & 41.6 \\
\hline & 3.000.000 - 3.000.000 IDR & 91 & 22.5 \\
\hline & Employed & 90 & 22.3 \\
\hline
\end{tabular}




\section{The Correlation of COVID-19 Awareness, Anxiety, Compliance on Social Distancing, and Age}

Based on the correlation test, awareness of COVID-19 is positively correlated with compliance on social distancing rules $(r=.460 ; p<0.01)$ and age $(r=.135 ; p<.01)$. This research is supported by previous findings that social distancing is significantly influenced by situational awareness (Qazi et al., 2020). (Qazi et al., 2020) state that increasing awareness of the situation during a public health crisis by using formal information sources (government, mass media) can improve protective health behaviors which in turn decreases the spread of disease viruses. Obtaining reliable information influence the decision to utilize any source of information provided (Calman, 2002) so that it leads to protective behavior in the form of personal hygiene and self-security (Johnson \& Hariharan, 2017). An awareness of COVID-19, individuals try to find and understand information about COVID-19 and take steps to prevent it.

Based on the Health Belief Model theory, individuals will take preventive steps determined by their perceptions of threats that can affect their health problems and the pros and cons they get in acting (Sarafino \& Smith, 2016). Awareness of COVID-19 will make individuals perceive COVID-19 as a disease that is dangerous to health so that individuals take action for prevention. To prevent COVID-19, individuals must have knowledge related to the etiology, transmission of viruses and their preventive measures (Mya et al., 2020). A basic understanding of influenza pandemic is related to willingness to comply with selfquarantine, avoid public activities, and reschedule of social gatherings (Eastwood et al., 2009). Awareness is a significant factor affecting the level of compliance (Shon et al., 2016).

Age was found to be positively correlated with awareness of COVID-19. These findings are supported by previous research that older individuals are more aware of the disease as shown by being aware of selfsafety (wearing masks) (Marshall et al., 2012), understanding spread of the virus (Kinariwala et al., 2020), actively involved in the COVID-19 prevention and treatment campaign (Labban et al., 2020). Thus the higher the awareness and more mature age people tend to be more obedient to the social distancing rules.

The results of subsequent analyzes showed that awareness of COVID-19 did not correlate with anxiety during the pandemic $(r=-.017, p>0.05)$. Having awareness about COVID-19 is not necessarily able to reduce anxiety. Previous research findings suggest that understanding of IBD (Inflammatory Bowel Disease) was not found to be related to anxiety (Hosni et al., 2019) although in other studies found otherwise (Panayiotou et al., 2018). Individuals who have more understanding of IBD knowledge have a tendency to have more anxiety. Getting a lot of information related to an illness can also make you more anxious. Internet media is a source of health information for the general public during the COVID-19. Social media which is a source of information relating to COVID-19 can be a cause of increased panic and worry (Balkhi et al., 2020; Roy et al., 2020). This is consistent with the statement that individuals who are too often exposed to news related to disaster events report higher stress (North \& Pfefferbaum, 2013). This relates to the media providing information about serious disaster events so as to increase anxiety (E. Lee \& Lee, 2019). The higher an individual is exposed to information will be COVID-19 and not filtering information properly will cause anxiety. However, the results of this research indicate that the level of awareness of COVID is relatively high and the level of anxiety is relatively low, there is no evidence-based finding that causes the two variables to be unrelated. 
Anxiety has a significant negative correlation with age $(r=-.331, p<.01)$ so that the more mature age, anxiety tends to be lower. This finding is supported by previous research which state older individuals show low levels of anxiety (Limcaoco et al., 2020). (Frazier et al., 2019) emphasize that there are three components that can explain decision making in older individuals, namely theory of mind, regulation of emotions and memories of past experiences.

\section{Table 3.}

\section{Spearman's Correlation rate between Variable}

\begin{tabular}{lcccc}
\hline & Awareness covid-19 & Anxiety & Compliance & Age \\
\hline Awareness COVID-19 & 1.000 & -.017 & $\mathbf{. 4 6 0 ^ { * * }}$ & $\mathbf{. 1 3 5 ^ { * * }}$ \\
\hline Anxiety & -.017 & 1.000 & -.01 & $\mathbf{- . 3 3 1 ^ { * * }}$ \\
\hline Compliance & $\mathbf{. 4 6 0 ^ { * * }}$ & -.021 & 1.000 & .037 \\
\hline Age & $\mathbf{. 1 3 5 * *}$ & $\mathbf{- . 3 3 1 * *}$ & .037 & 1.000 \\
\hline
\end{tabular}

*^Significant Correlation on the level 0.01 (2-tailed)

* Significant Correlation on the level 0.05 (2-tailed)

\section{Awareness of COVID-19}

Table 4 shows that awareness of COVID-19 was found to be significantly higher in working individuals $(U=$ $17261, p<.05)$ compared to non-working individuals. Individuals who work more aware of COVID-19 because some of them still work or do picket in the office so they are aware of the need for self-protection to prevent COVID-19 while working. Rabinowitz et al., (2013) report that workers being aware of the risk of influenza by showing $78 \%$ of workers paying attention to influenza infection, $93 \%$ of workers is bathing after outside, $97 \%$ of workers participating in health programs and work safety, and $93 \%$ of workers are aware of following influenza guidelines. Workers also report using personal protective equipment and washing their hands after work.

Awareness of COVID-19 differed significantly based on education level $(H=4,641, p<.01)$. Then the MannWhitney Test was conducted to follow up this difference which can be seen in table 6. Bonferroni correction was used and all tests were reported at a significance level of 0.167 (obtained from .05 / number of tests (6). The test results found that there were no differences in awareness towards COVID-19 between high school graduates and undergraduate $(U=8558.5, p>.0167)$ or between undergraduate and Postgraduate ( $U$ $=7317, \mathrm{p}>$.0167). However, awareness of COVID-19 was significantly higher in Postgraduate graduates compared to graduates of Senior High School $(U=7242, p<.0167)$ This is in line with the findings of Bawazir et al., (2018) who stated that the higher level of education will affect individual and group awareness of preventing the spread of pandemic outbreaks. In another side, Labban et al., (2020) also shows that educational backgrounds distinguish the level of awareness of COVID 19, namely individuals who graduate from a higher level of awareness. The results of this research showed there were no differences in awareness of COVID-19 based on gender $(U=140680.5, p>.05)$, age $(H=4,461, p>.05)$ and income level $(H=7,768, p>.05)$. 
Table 4.

The Analysis of Mann-Whitney $U$ toward Awareness of COVID-19, Anxiety, and Compliance on Social Distancing is seen from Gender and Work Status

\begin{tabular}{|c|c|c|c|c|c|c|c|c|c|}
\hline \multirow[t]{2}{*}{ Variable and Distribution (n) } & \multicolumn{4}{|c|}{ Awareness of COVID-19 } & \multicolumn{2}{|l|}{ Anxiety } & \multicolumn{3}{|c|}{ Compliance on Social Distancing } \\
\hline & Mdn & $U$ & $p$ & Mdn & $U$ & $p$ & Mdn & $U$ & $P$ \\
\hline \multicolumn{10}{|l|}{ Gender } \\
\hline Male & 70 & 14080.5 & .547 & 3 & 10412.5 & .000 & 51 & 12031.5 & .008 \\
\hline Female & 70 & & & 6 & & & 54 & & \\
\hline \multicolumn{10}{|l|}{ Work Status } \\
\hline Employed & 69 & 17261.0 & .021 & 7 & 13961.0 & .000 & 54 & 18469.5 & .210 \\
\hline Unemployed & 71 & & & 4 & & & 53 & & \\
\hline
\end{tabular}

\section{Anxiety}

The Covid-19 pandemic raises new problems that have implications for areas such as Economics (Laing, 2020), Psychologists (Temsah et al., 2020), and Psychosocial (Dubey et al., 2020). This condition triggers anxiety in the community (Özdin \& Bayrak Özdin, 2020).

Based on the results of the analysis in table 4, there are differences in anxiety in terms of gender $(\mathrm{U}=$ 10412.5, $p>$.01). Female (Mdn = 6) have higher anxiety than Male $(\mathrm{Mdn}=3)$. This shows that the psychiatric impact during the COVID-19 pandemic was greater in Female. Previous studies have shown that anxiety disorders are more common in female (Alexander et al., 2007; Elbay et al., 2020; Maaravi \& Heller, 2020). Female has been identified as the most powerful predictor of post-traumatic stress disorder symptoms after the pandemic (Liu et al., 2020). In a study from China, although female knew more about the disease than male during the COVID-19 pandemic and obeyed more advice, such as wearing masks and avoiding public spaces, they also reported not knowing whether the pandemic could be controlled or the probability of such control being established (Zhong et al., 2020). Female more experience the anxiety because they have more metacognitive beliefs about the inability to control their anxious and believe that worried should be avoided (Bahrami \& Yousefi, 2011).

Anxiety was also significantly higher in individuals who unemployed $(U=13971, p<.01)$ than individuals who employed. The results of previous studies indicate that work status is correlated with anxiety. Work has an important role in giving an indication of someone's status in society, and of course in front of his family. While the unemployed do not have the opportunity to move and must continue to look for activities to maintain their activity. Work will make the time more structured. Activities to be carried out every day, every week, every month and so on will be clearer. The loss of this structure can cause a loss of time orientation, which can eventually cause anxiety symptoms. Unemployed do not have employment status and identity, and this will reduce their self-esteem (Isnaini \& Lestari, 2016).

In table 5, based on testing by Kruskal Wallis, anxiety differed significantly by age $(H=27,691, p<.01)$, education level $(H=38.956, p<.01)$, and income level $(H=22981, p<.01)$. The Mann-Whitney Test was carried out to follow up these differences listed in table 6 . Bonferroni correction was used and all tests were reported at a significance level of .0167 (obtained from .05 / the number of Mann Whitney tests performed 
ie 3) for differences test based on age and level education. Then the confidence level of .0083 (obtained from .05 divided by the number of Mann Whitney tests performed is 6 ) to test differences based on income levels.

Based on table 6, there were no differences in anxiety in the age groups 31-45 and $>46(U=622.5, p>$ .0167). Anxiety was significantly higher at ages $18-30$ compared to ages $31-45(U=8991, p<.0167)$ and compared to age $46(U=1481.5, p<.0167)$. This means that younger adult individuals have a risk of having more anxiety than older adult individuals. Previous studies conducted by Elbay et al., (2020); S. A. Lee, (2020) showing that younger adults have more anxiety about COVID-19. (Limcaoco et al., 2020) also said that older individuals showed lower levels of anxiety even though this group was reported as having a high risk of contracting COVID-19 while young adult individuals had higher stress levels because they showed concern about being infected with COVID- 19.

On anxiety based on education level (see table 5), the test results found no difference in anxiety in high school and undergraduate $(U=8381.5, p>.0167)$. Anxiety was significantly lower in Postgraduate than in SMA $(U=5475, p<.0167)$ and compared to Undergraduate $(U=5725.5, p<.0167)$. Respondents with postgraduate level are more sensitive to information about COVID-19 so that it is easier to manage anxiety (Roy et al., 2020).

In income-based anxiety (see table 5), the test results show that there is no difference in anxiety between 1.000.000-3.000.000 income respondents and 3.000.000-5.000.000 income $(U=3839, p>.0083)$ and those with an income $>5.000 .000(U=2333, p>.0083)$. There was no difference in anxiety between respondents earning 3.000.000-5.000.000 and those $>5.000 .000(U=2475, p<.0083)$. Anxiety was found to be significantly higher in the group with income $<1.000 .000$ compared to 1.000.000-3.000.000 (U = 5713.5, $p$ $<.0083), 3.000 .000-5.000 .000(U=5461.0, p<.0083)$, and $>5.000 .000(U=3182, P<.0083)$. In this case it means that higher anxiety is found in individuals who have incomes below Rp. 1.000.000. A study noted that the majority of respondents were concerned about financial limitations during the "lockdown", nearly a quarter experienced symptoms of depression and one third found it difficult to adjust to these "new normal" conditions (Kaustav \& Moumita, 2020). Some community groups generally have a high prevalence of general psychiatric disorders, such as depression, anxiety and poor quality of life, which can further be dangerous due to the "lockdown" imposed by the government and loss of income during the onset of the COVID-19 pandemic (Truman et al., 2009).

When anxiety affects a larger population, it affects to people in the outside for shopping to excess needs (panic buying), thus resulting in scarcity of goods. This condition also results in limitations in daily activities, avoidance behavior caused by limited socialization, self-medication. Because of anxiety, people adopt various lifestyle and unwanted diet modifications under the influence of rumors. This condition can affect mental health. Likewise, additional changes such as isolation, social distance, quarantine itself, travel restrictions and the amount of hoax information that continues to spread on social media also tend to be bad for mental health. 
Table 5.

The Analysis of Kruskal Wallis toward Awareness of COVID-19, Anxiety, and Compliance on Social Distancing is seen from Age, Education and Income

\begin{tabular}{|c|c|c|c|c|c|c|c|c|c|}
\hline \multirow[t]{2}{*}{ Variable and Distribution (n) } & \multicolumn{3}{|c|}{ Awareness COVID-19 } & \multicolumn{3}{|c|}{ Anxiety } & \multicolumn{3}{|c|}{ Compliance on Social Distancing } \\
\hline & Mdn & $H$ & $p$ & Mdn & $H$ & $p$ & Mdn & $H$ & $p$ \\
\hline \multicolumn{10}{|l|}{ Age } \\
\hline $18-30$ & 70 & 4.641 & .098 & 6 & 27.691 & .000 & 54 & 2.679 & .262 \\
\hline $31-45$ & 71 & & & 4 & & & 54 & & \\
\hline$>46$ & 69.5 & & & 2 & & & 54 & & \\
\hline \multicolumn{10}{|l|}{ Education } \\
\hline SMA & 69 & 10.457 & .005 & 7 & 38.956 & .000 & 54 & 3.149 & .207 \\
\hline Undergraduate & 70 & & & 6 & & & 53 & & \\
\hline Postgraduate & 71 & & & 4 & & & 54 & & \\
\hline \multicolumn{10}{|l|}{ Income } \\
\hline$<1.000 .000$ IDR & 69 & 7.768 & .051 & 7 & 22.981 & .000 & 54 & 1.640 & .650 \\
\hline 1.000.000-3.000.000 IDR & 71 & & & 5 & & & 54 & & \\
\hline 3.000.000-5.000.000 IDR & 70.5 & & & 4 & & & 54 & & \\
\hline$>5.000 .000 \mathrm{IDR}$ & 71 & & & 4 & & & 52 & & \\
\hline
\end{tabular}

Table 6.

The Analysis of Mann-Whitney $U$ for Post hoc test from result of Kruskall Wallis toward Awareness of COVID-19, Anxiety, and Compliance on Social Distancing is seen from Age, Education and Income 


\begin{tabular}{|c|c|c|c|c|c|c|}
\hline \multirow[t]{2}{*}{ Variable and Distribution (n) } & \multicolumn{3}{|c|}{ Awareness of COVID-19 } & \multicolumn{3}{|c|}{ Anxiety } \\
\hline & Mdn & $U$ & $p$ & Mdn & $U$ & $p$ \\
\hline \multicolumn{7}{|l|}{ Age } \\
\hline $18-30$ & & & & 6 & 8991.0 & .000 \\
\hline $31-45$ & & & & 4 & & \\
\hline $18-30$ & & & & 6 & 1481.5 & .000 \\
\hline$>46$ & & & & 2 & & \\
\hline $31-45$ & & & & 4 & 633.5 & .071 \\
\hline$>46$ & & & & 2 & & \\
\hline \multicolumn{7}{|l|}{ Education } \\
\hline Senior High School & 69 & 8558.5 & .253 & 7 & 8381.5 & .157 \\
\hline Undergraduate & 70 & & & 6 & & \\
\hline SMA & 69 & 7242.5 & .002 & 7 & 5475.0 & .000 \\
\hline Postgraduate & 71 & & & 4 & & \\
\hline Undergraduate & 70 & 7317.0 & .038 & 6 & 5725.5 & .000 \\
\hline Postgraduate & 71 & & & 4 & & \\
\hline \multicolumn{7}{|l|}{ Income } \\
\hline$<1.000 .000 \mathrm{IDR}$ & & & & 7 & 5713.5 & .001 \\
\hline 1.000.000-3.000.000 IDR & & & & 5 & & \\
\hline$<1.000 .000 \mathrm{IDR}$ & & & & 7 & 5461.0 & .000 \\
\hline 3.000.000-5.000.000 IDR & & & & 4 & & \\
\hline$<1.000 .000 \mathrm{IDR}$ & & & & 7 & 3182.0 & .001 \\
\hline$>5.000 .000 \mathrm{IDR}$ & & & & 4 & & \\
\hline 1.000.000-3.000.000 IDR & & & & 5 & 3839 & .466 \\
\hline 3.000.000-5.000.000 IDR & & & & 4 & & \\
\hline 1.000.000-3.000.000 IDR & & & & 5 & 2333.0 & .492 \\
\hline$>5.000 .000 \mathrm{IDR}$ & & & & 4 & & \\
\hline 3.000.000-5.000.000 IDR & & & & 4 & 2475.0 & 1.000 \\
\hline$>5.000 .000 \mathrm{IDR}$ & & & & 4 & & \\
\hline
\end{tabular}

\section{Compliance on Social Distancing}

Table 4 shows that adherence to social distancing was higher in female $(M d n=54)$ than male $(M d n=51)$ $(U=12031.5, p<.01)$. Compliance was found to be no different between employed and unemployed individuals $(U=19546, p>.05)$. Based on testing by Kruskal Wallis in table 5 , there is no difference in compliance with social distancing rules seen from the level of age $(H=2,679, p>$. 05), education $(H=3,149$, $p>$. 05), and income ( $H=1,640, p>.05)$.

Most female are more willing to obey Stay at Home policies than men is possible because female display more positive health-related behaviors so they are more adherent to policies related to social distancing in order to prevent the higher spread of COVID-19 (Bass et al., 2010). This finding reinforces the research findings of Marshall et al., (2012) that when facing H1N1 in 2007 and 2009, women were more obedient for wearing masks and complied with Stay at Home policy. Work status, age, education, and income did not appear to distinguish compliance in this research. This might be because in general the respondents' compliance in this research was seen by various groups as quite high with the lowest compliance score of 39 to the highest score of 60 .

\section{Conclusion}


The research found that individuals are more mature, working, and highly educated to have higher COVID19 awareness. Groups that need more attention are related to awareness of COVID-19 and are more at risk of experiencing anxiety, namely younger age groups, less educated, and not working. The results also found that awareness of COVID-19 was positively correlated with compliance on social distancing rules. It is important for the government to provide an official information channel to conduct more massive socialization to the public about COVID-19 in order to raise awareness about COVID-19. With a website or official information source that is easily accessible will minimize the misinformation or HOAX related to COVID-19. The government as the policy maker also needs to develop a clear prevention plan which is then communicated to the public. Regarding the discourse on the implementation of New Normal, the government needs to make realistic guidelines on how the community must obey the rules and behave according to the recommended health protocol. Younger age groups, lower education, and lower income who have a higher risk of experiencing anxiety need to be given more attention.

From this research it can be learned that the issue that says to the society with low education and low income only need to be fed during the implementation of the Large Scale Social Restrictions (LSSR) is not entirely correct. Society in this category also need information relating to the Covid-19 pandemic.

\section{Declaration}

\section{LIMITATIONS}

In Data collection conducted online through Google Form is own limitation for this research. There may be groups that cannot be reached as research respondents, the groups that are not familiar with online filling such as groups with lower education and older age. Research respondents who are high school graduates in this research are mostly students who belong to the highly educated group. This might be the cause of the data in this research that is not normally distributed, namely awareness of COVID-9 is relatively high, anxiety is relatively low, and compliance is relatively high. Variable of compliance with government policies in order to prevent the spread of COVID-19 needs to be supported by many parties and needs to be examined from various other variables such as public political trust (Painter \& Qiu, 2020) to get a more comprehensive descriptions of what factors can predict community compliance other than awareness of COVID-19 has been investigated in this research.

\section{COMPLIANCE WITH ETHICAL STANDARDS}

Conflict of Interest: The authors have no conflicts of interest to declare that are relevant to the content of this article. All authors certify that they have no affiliations with or involvement in any organization or entity with any financial interest or non-financial interest in the subject matter or materials discussed in this manuscript. 
Ethical approval: "All procedures performed in studies involving human participants were in accordance with the ethical standards of the health research ethics committee, Faculty of health, Aisyah University of Pringsewu with number 212 /UAP20/5/EA/2020 and with the 1964 Helsinki declaration and its later amendments or comparable ethical standards."

Informed consent: "Informed consent was obtained from all individual participants included in the study."

\section{References}

Ahmed, F., Zviedrite, N., \& Uzicanin, A. (2018). Effectiveness of workplace social distancing measures in reducing influenza transmission: A systematic review. BMC Public Health, 18(1), 1-13. https://doi.org/10.1186/s12889-018-5446-1

Alexander, J. L., Dennerstein, L., Kotz, K., \& Richardson, G. (2007). Women, anxiety and mood: a review of nomenclature, comorbidity and epidemiology. Expert Review of Neurotherapeutics, 7(sup1), S45-S58. https://doi.org/10.1586/14737175.7.11s.S45

Bahrami, F., \& Yousefi, N. (2011). Females are more anxious than males: a metacognitive perspective. Iranian Journal of Psychiatry and Behavioral Sciences, 5(2), 83-90.

https://pubmed.ncbi.nlm.nih.gov/24644451

Balkhi, F., Nasir, A., Zehra, A., \& Riaz, R. (2020). Psychological and Behavioral Response to the Coronavirus (COVID-19) Pandemic. Cureus, 12(5), e7923. https://doi.org/doi.org/10.7759/cureus.7923

Bass, S. B., Ruzek, S. B., Ward, L., Gordon, T. F., Hanlon, A., Hausman, A. J., \& Hagen, M. (2010). If you ask them, will they come? predictors of quarantine compliance during a hypothetical avian influenza pandemic: Results from a statewide survey. Disaster Medicine and Public Health Preparedness, 4(2), 135-144. https://doi.org/10.1001/dmphp.D-09-00052R2

Bawazir, A., Al-Mazroo, E., Jradi, H., Ahmed, A., \& Badri, M. (2018). MERS-CoV infection: Mind the public knowledge gap. Journal of Infection and Public Health, 11(1), 89-93.

https://doi.org/https://doi.org/10.1016/j.jiph.2017.05.003

Calman, K. C. (2002). Communication of risk: choice, consent, and trust. The Lancet, 360(9327), 166-168. https://doi.org/10.1016/S0140-6736(02)09421-7

Cao, Q., Zhao, H., Yao, J., \& Liang, Y. (2019). Anxiety and sleep quality in Chinese persons with a substance use disorder: A moderated mediation model of rumination and mindfulness. Current Psychology. https://doi.org/10.1007/s12144-019-00200-5

Damanik, E. D. (2006). Pengujian reliabilitas, validitas, analisis item dan pembuatan norma Depression Anxiety Stress Scale (DASS): Berdasarkan penelitian pada kelompok sampel Yogyakarta dan Bantul yang mengalami gempa. Universitas Indonesia. 
Damanik, E. D. (2011). DASS42 Bahasa Indonesia Damanik.

http://www2.psy.unsw.edu.au/dass/Indonesian/Damanik.htm

Dubey, S., Biswas, P., Ghosh, R., Chatterjee, S., Dubey, M. J., Chatterjee, S., Lahiri, D., \& Lavie, C. J. (2020). Psychosocial impact of COVID-19. Diabetes \& Metabolic Syndrome: Clinical Research \& Reviews. https://doi.org/https://doi.org/10.1016/j.dsx.2020.05.035

Eastwood, K., Durrheim, D., Francis, J. L., d'Espaignet, E. T., Duncan, S., Islam, F., \& Speare, R. (2009). Knowledge about pandemic influenza and compliance with containment measures among Australians. Bulletin of the World Health Organization, 87(8), 588-594. https://doi.org/10.2471/blt.08.060772

Elbay, R. Y., Kurtulmuş, A., Arpacıoğlu, S., \& Karadere, E. (2020). Depression, anxiety, stress levels of physicians and associated factors in Covid-19 pandemics. Psychiatry Research, 290(May), 1-5. https://doi.org/10.1016/j.psychres.2020.113130

Field, A. (2009). Discovering statistics using SPSS: (and sex and drugs and rock "n" roll). SAGE. http://sro.sussex.ac.uk/id/eprint/14911/

Frazier, I., Lighthall, N. R., Horta, M., Perez, E., \& Ebner, N. C. (2019). CISDA: Changes in Integration for Social Decisions in Aging. WIREs Cognitive Science, 10(3), e1490. https://doi.org/10.1002/wcs.1490

Ho, C. S., Chee, C. Y., \& Ho, R. C. (2020). Mental Health Strategies to Combat the Psychological Impact of COVID-19 Beyond Paranoia and Panic. Annals of the Academy of Medicine, Singapore, 49(1), 1-3.

Hosni, M., Hamade, A., ElKhoury, H., Kfouri, J., Chahrour, M., Kahlifeh, J., Saadeh, S., Kattouf, N., Sharara, A., Francis, F., Mourad, F., Soweid, A., Daniel, F., Binion, D., \& Hashash, J. (2019). P032 Does Patient Knowledge Affect Anxiety, Depression, and Quality of Life in Patients With Inflammatory Bowel Disease? American Journal of Gastroenterology, 114.

https://journals.Iww.com/ajg/Fulltext/2019/12001/P032_Does_Patient_Knowledge_Affect_Anxiety,.33.aspx

Ifdil, I., Fadli, R. P., Suranata, K., Zola, N., \& Ardi, Z. (2020). Online mental health services in Indonesia during the COVID-19 outbreak. Asian Journal of Psychiatry, 51(April), 102153.

https://doi.org/10.1016/j.ajp.2020.102153

Isnaini, N. S. N., \& Lestari, R. (2016). KECEMASAN PADA PENGANGGURAN TERDIDIK LULUSAN UNIVERSITAS. Indigenous: Jurnal IImiah Psikologi; Vol. 13, No.1, Mei 2015DO 10.23917/Indigenous.V13i1.2322 . http://journals.ums.ac.id/index.php/indigenous/article/view/2322

Johnson, E. J., \& Hariharan, S. (2017). Public health awareness: knowledge, attitude and behaviour of the general public on health risks during the H1N1 influenza pandemic. Journal of Public Health, 25(3), 333337. https://doi.org/10.1007/s10389-017-0790-7

Kaustav, C., \& Moumita, C. (2020). Psychological impact of COVID-19 pandemic on general population in West Bengal: A cross-sectional study. Indian Journal Psychiatry, 62(3), 266-272. 
https://doi.org/10.4103/psychiatry.IndianJPsychiatry_276_20

Kinariwala, N., Samaranayake, L., Perera, I., \& Patel, Z. (2020). Knowledge, Awareness and Perceptions of Coronavirus Disease 2019 (COVID-19) in a Cohort of Indian Dental Professionals: A Questionnaire-Based Study. Preprints, 2020050442. https://doi.org/https://doi.org/10.20944/preprints202005.0442.v1

Kunjana, G. (2020). Baru 2 Provinsi dan 22 Kabupaten/Kota yang Terapkan PSBB. https://investor.id/national/baru-2-provinsi-dan-22-kabupatenkota-yang-terapkan-psbb

Kurniawan, H. (2020). PSBB Tangsel, Airin: Kepatuhan masyarakat baru 60 persen.

https://www.inews.id/news/megapolitan/psbb-tangsel-airin-kepatuhan-masyarakat-baru-60-persen

Labban, L., Thallaj, N., \& Labban, A. (2020). Assessing the Level of Awareness and Knowledge of COVID 19 Pandemic among Syrians. Archives of Medicine, 12(2), 8. https://doi.org/10.36648/1989-5216.12.2.309

Laing, T. (2020). The economic impact of the Coronavirus 2019 (Covid-2019): Implications for the mining industry. The Extractive Industries and Society. https://doi.org/https://doi.org/10.1016/j.exis.2020.04.003

Lee, E., \& Lee, H. (2019). Disaster awareness and coping: Impact on stress, anxiety, and depression. Perspectives in Psychiatric Care, 55(2), 311-318. https://doi.org/10.1111/ppc.12351

Lee, S. A. (2020). Coronavirus Anxiety Scale: A brief mental health screener for COVID-19 related anxiety. Death Studies, 44(7), 393-401. https://doi.org/10.1080/07481187.2020.1748481

Limcaoco, R. S. G., Mateos, E. M., Fernandez, J. M., \& Roncero, C. (2020). Anxiety, worry and perceived stress in the world due to the COVID-19 pandemic, March 2020. Preliminary results. MedRxiv, 2020.04.03.20043992. https://doi.org/10.1101/2020.04.03.20043992

Liu, N., Zhang, F., Wei, C., Jia, Y., Shang, Z., Sun, L., Wu, L., Sun, Z., Zhou, Y., Wang, Y., \& Liu, W. (2020). Prevalence and predictors of PTSS during COVID-19 outbreak in China hardest-hit areas: Gender differences matter. Psychiatry Research, 287, 112921. https://doi.org/https://doi.org/10.1016/j.psychres.2020.112921

Lovibond, P. F., \& Lovibond, S. H. (1995). The structure of negative emotional states: Comparison of the Depression Anxiety Stress Scale (DASS) with the Beck Depression and Anxiety Inventory. Behav Res. Ther, 33(3), 335-343. https://doi.org/10.1007/BF02511245

Maaravi, Y., \& Heller, B. (2020). Not all worries were created equal: The case of COVID-19 anxiety. Public Health. https://doi.org/10.1016/j.puhe.2020.06.032

Marshall, H., Tooher, R., Collins, J., Mensah, F., Braunack-Mayer, A., Street, J., \& Ryan, P. (2012). Awareness, anxiety, compliance: Community perceptions and response to the threat and reality of an influenza pandemic. American Journal of Infection Control, 40(3), 270-272.

https://doi.org/10.1016/j.ajic.2011.03.015 
Milne, G. J., \& Xie, S. (2020). The Effectiveness of Social Distancing in Mitigating COVID-19 Spread: a modelling analysis. MedRxiv, 2020.03.20.20040055. https://doi.org/10.1101/2020.03.20.20040055

Mishra, P., Bhadauria, U. S., Dasar, P. L., N, S., Kumar, S., Lalani, A., Sarkar, P., Chauhan, A., Godha, S., \& Vyas, S. (2016). Knowledge,attitude and anxiety towards pandemic flu a potential bio weapon among health professionals in Indore City. Przeglad Epidemiologiczny, 70(1), 41-45,125-127.

Mya, K. S., S. M., A., Hlaing, W. A., Hlaing, S. S., Aung, T., Lwin, S. M. M., S. U., E., Tun, T., Lwin, K. S., \& Win, H. H. (2020). Awareness, perceived risk and protective behaviours of Myanmar adults on COVID-19. International Journal Of Community Medicine And Public Health; Vol 7, No 5 (2020): May 2020. https://doi.org/10.18203/2394-6040.ijcmph20201530

North, C. S., \& Pfefferbaum, B. (2013). Mental Health Response to Community Disasters: A Systematic Review. JAMA, 310(5), 507-518. https://doi.org/10.1001/jama.2013.107799

Özdin, S., \& Bayrak Özdin, Ş. (2020). Levels and predictors of anxiety, depression and health anxiety during COVID-19 pandemic in Turkish society: The importance of gender. International Journal of Social Psychiatry, 0020764020927051. https://doi.org/10.1177/0020764020927051

Page, A. C., Hooke, G. R., \& Morrison, D. L. (2007). Psychometric properties of the Depression Anxiety Stress Scales (DASS) in depressed clinical samples. British Journal of Clinical Psychology, 46(3), 283-297. https://doi.org/10.1348/014466506X158996

Painter, M., \& Qiu, T. (2020). Political Beliefs affect Compliance with COVID-19 Social Distancing Orders. SSRN Electronic Journal. https://doi.org/10.2139/ssrn.3569098

Panayiotou, G., Leonidou, C., Constantinou, E., \& Michaelides, M. P. (2018). Self-Awareness in alexithymia and associations with social anxiety. Current Psychology. https://doi.org/10.1007/s12144-018-9855-1

Qazi, A., Qazi, J., Naseer, K., Zeeshan, M., Hardaker, G., Maitama, J. Z., \& Haruna, K. (2020). Analyzing situational awareness through public opinion to predict adoption of social distancing amid pandemic COVID-19. Journal of Medical Virology, 0-2. https://doi.org/10.1002/jmv.25840

Rabinowitz, P. M., Huang, E., Paccha, B., Vegso, S., \& Gurzau, A. (2013). Awareness and practices regarding zoonotic influenza prevention in Romanian swine workers. Influenza and Other Respiratory Viruses, 7(s4), 27-31. https://doi.org/10.1111/irv.12191

Roy, D., Tripathy, S., Kar, S. K., Sharma, N., Verma, S. K., \& Kaushal, V. (2020). Study of knowledge, attitude, anxiety \& perceived mental healthcare need in Indian population during COVID-19 pandemic. Asian Journal of Psychiatry, 51, 102083. https://doi.org/https://doi.org/10.1016/j.ajp.2020.102083

Sarafino, E. P., \& Smith, T. W. (2016). Health Psychology: Biopsychosocial Interactions (9th Editio). John Wiley \& Sons, Inc. https://www.wiley.com/en-

us/Health+Psychology\%3A+Biopsychosocial+Interactions\%2C+9th+Edition-p-9781119299486

Page 15/16 
Shon, J.-A., Yang, Y., \& Park, J. H. (2016). Factors Influencing Compliance for Influenza Infection Control by Nurses. J Korean Acad Fundam Nurs, 23(2), 161-171. https://doi.org/10.7739/jkafn.2016.23.2.161

Temsah, M.-H., Al-Sohime, F., Alamro, N., Al-Eyadhy, A., Al-Hasan, K., Jamal, A., Al-Maglouth, I., Aljamaan, F., Al Amri, M., Barry, M., Al-Subaie, S., \& Somily, A. M. (2020). The psychological impact of COVID-19 pandemic on health care workers in a MERS-CoV endemic country. Journal of Infection and Public Health. https://doi.org/https://doi.org/10.1016/j.jiph.2020.05.021

Truman, B. I., Tinker, T., Vaughan, E., Kapella, B. K., Brenden, M., Woznica, C. V, Rios, E., \& Lichtveld, M. (2009). Pandemic influenza preparedness and response among immigrants and refugees. American Journal of Public Health, 99 Suppl 2(Suppl 2), S278-86. https://doi.org/10.2105/AJPH.2008.154054

Wang, Y., Di, Y., Ye, J., \& Wei, W. (2020). Study on the public psychological states and its related factors during the outbreak of coronavirus disease 2019 (COVID-19) in some regions of China. Psychology, Health \& Medicine, 1-10. https://doi.org/10.1080/13548506.2020.1746817

WHO. (2020a). Coronavirus Disease (COVID-19) Outbreak: Rights, Roles And Responsibilities Of Health Workers, Including Key Considerations For Occupational Safety And Health. https://www.who.int/docs/default-source/coronaviruse/who-rights-roles-respon-hw-covid-19.pdf? sfvrsn=bcabd401_0

WHO. (2020b). Update on coronavirus disease in Indonesia. https://www.who.int/indonesia/news/novelcoronavirus

Yusuf, T. A. (2020). Tingkat Kesadaran Masyarakat dalam Social and Physical Distancing Masih Rendah. https://harianpelita.co/2020/04/08/tingkat-kesadaran-masyarakat-dalam-social-and-physical-distancingmasih-rendah/

Zhong, B.-L., Luo, W., Li, H.-M., Zhang, Q.-Q., Liu, X.-G., Li, W.-T., \& Li, Y. (2020). Knowledge, attitudes, and practices towards COVID-19 among Chinese residents during the rapid rise period of the COVID-19 outbreak: a quick online cross-sectional survey. International Journal of Biological Sciences, 16(10), 1745-1752. https://doi.org/10.7150/ijbs.45221

\section{Supplementary Files}

This is a list of supplementary files associated with this preprint. Click to download.

- Covid19ResearchTabulation.xlsx 